\title{
Hygiene Practice and Protective Management in Biological and Pharmaceutical Laboratory
}

\author{
Mst. Nasrin Banu1,a , Md. Salauddin, ${ }^{2, b,}$, Kazi Md. Al Noman ${ }^{3, c}$, Mst. Shabnam Mostari, ${ }^{4, d}$, Md. Suruj \\ Ahammed $^{5, \mathrm{e}}$, Md. Masud Parvej6,f \\ ${ }^{1}$ Department of Paraclinical Courses, Faculty of Veterinary and Animal Sciences, Gono Bishwabidyalay, Dhaka-1344, Bangladesh \\ ${ }^{2}$ Department of Microbiology and Public Health, Faculty of Veterinary, Animal and Biomedical Sciences, Khulna Agricultural University, \\ Khulna-9100, Bangladesh \\ ${ }^{3}$ Department of Animal production, Faculty of Veterinary and Animal Sciences, Gono Bishwabidyalay, Dhaka-1344, Bangladesh \\ ${ }^{4}$ Faculty of Veterinary and Animal Science, Hajee Mohammad Danesh Science and Technology University, Dinajpur-5200, Bangladesh \\ ${ }^{5}$ Department of Chemistry, Faculty of Science, Begum Rokeya University, Rangpur-5404 Bangladesh \\ ${ }^{6}$ Department of Preclinical Courses, Faculty of Veterinary and Animal Sciences, Gono Bishwabidyalay, Dhaka -1344, Bangladesh \\ *Corresponding author
}

\begin{tabular}{l|l}
$\begin{array}{l}\text { A R T I C L E I N F O } \\
\text { Review Article }\end{array}$ & $\begin{array}{l}\text { Throughout the world, Pharmaceutical sector is an instant component in health-care systems. It } \\
\text { involved in invention, improvement, propagation, and trading of medicines for human health and } \\
\text { animal health. Scientific investigation is the base of pharmaceutical industries which helps to } \\
\text { improve of new formulation of various drugs that used to treatment of different diseases and } \\
\text { confusions. Proper personal hygiene is mandatory in pharmaceutical sector which will be helpful to } \\
\text { control the quality of the products and minimize various types of filth that effects virtue of medicinal } \\
\text { product. In pharmaceutical industry hygienic and safety measures are deliberated two utmost } \\
\text { significant sights. To ensure the safety of workers, it is compulsory to fix practices of hygienic } \\
\text { management and monitoring filth inside the biological and pharma laboratory as well as industry. } \\
\text { Accepted : } 25 / 06 / 2021 \\
\text { This study will help to set an occupational health of the researchers, workers in laboratory by } \\
\text { making intimation about the bad effects of personal hygiene and less protective management. } \\
\text { Biological laboratory } \\
\text { Pharmaceutical laboratory }\end{array}$
\end{tabular}

Hygiene practice

Chemical and industrial hazards

Workplace safety

nasrinmoon0702@gmail.com kazialnoman51@gmail.com

surujchem@gmail.com (i) http://orcid.org/0000-0002-3249-0847
(iD) http://orcid.org/0000-0002-2001-6232
(iD) http://orcid.org/0000-0001-7246-681X

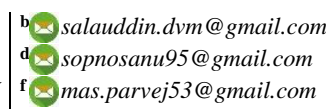

(D) http://orcid.org/0000-0002-8990-3868 http://orcid.org/0000-0002-9819-1567 http://orcid.org/0000-0002-5709-8729

\section{Introduction}

In making of pharmaceuticals, foodstuff, different cosmetics and several products, proper hygiene is a troublesome element. Personal hygiene is an important component in public health and it includes most of the defensive meters, which influence the happiness and affluence of an individual (Pal M, 2007). Different practices in personal hygiene i.e., washing hands properly and regularly brushing of teeth keep away of different pathogen from our bodies. In addition, these practices will be helpful to boost up our mental health status and activities (Bassam Abdul Rasool Hassan, 2012). Personal Protective Equipment (PPE) can comprise different items like safety helmets, safety harnesses, eye protection, ear plugs hazmat suits, high-visibility clothing, gloves, ear defenders and safety footwear. Disposable PPE may be single-use coveralls in peculiar situations (PIG, 2019).

Hazard is a condition that gesture an intimidation to life, health properties and environment. Hazardous elements are basically chemical products that can gesture an intimidation to health. It includes agricultural chemicals, pharmaceuticals, cosmetic, industrial chemicals, food chemicals and different types of pesticide that "have a negative impact on health of workers due to immediate exposure or contact with this chemical matter (UMDNJ, 2001). Industrial hazard may be defined as any situation created by industries that can motive. Injury or death to personnel or loss of product or property (Hazard Guidelines, 2011). Detrimental effect occurs in human and 
environments by manufacturing, synthesis, processing, distribution and transportation of chemical is known as chemical hazard. Chemical hazard is one of the professional hazards that is concerned by exposure to chemical mater. Exposure to chemicals in workplace can motive acute or long-term exaggerated health effects. Multiple types of hazards of chemicals are available including dermatologic agents, immune agents, carcinogens, systemic toxins, neurotoxins, reproductive toxins, sensitizers and pneumoconiotic agent (FDA, 2020; Hughes Safety Showers, 2020). The unavoidable steps leading to the safe usages of chemicals is sense of their health hazards. It must be attainable with a reasonable cost and endeavor. Moreover, this intrinsically complicated learning must be embodied in a same measure that premier fact on incidental dangers and defensive meters can be recognized and dispatched to the buyer in an easy to perceive way (UMDNJ, 2001). This review predicts for the safe handling of hazardous chemicals in laboratories to provide guidance by laboratory safety and chemical hygiene plan. Pharmaceutics worker those are involved in the production and stirring of medicinal products are ever manifested to chemical setback. Moreover, they orderly come to concern with different things like aerosol construction, fluids, mote and fragments - if enough prophylactive meters are fulfill all of which can result into better health. It is advisable not to avoid of appeasement hygiene and safety standards which leads to pharmaceutical filth, having great consequences on product quality, merchandise nutriment and patent safety non-committal. The purpose of this review to ensure Lab Research Safety Program is to reduce the risk of injury or illness to laboratory workers by ascertain that they have the information, support, training and equipment needed to work safely in the laboratory.

\section{Health and Security in Pharmaceutical Industry}

In the pharmaceutical industries, it is difficult to sustain health status and safety. It is very important for all employees to oblige workplace safety standards (HSE, 1999). Any condition created by industries or laboratory causes injury or death to personal or property may define as hazard (Abdul Hafeez et al., 2020). the way or procedure by which hazards reduce from the industries or laboratory refers as safety (ILO, 2020). Different health protection measures and effective management of worker safety may reduce the extent and severity of work-related injuries and sicknesses and their related costs (Herman AM, 2020). Working with chemicals have the chance of exposure which will hazardous to a person's health. Those health risks are dependent upon the toxicity of the chemical, the types of effects. Hazardous chemicals can enter the body through the respiratory tract through inhalation (Chemical Hazards, 2012). The objective of industrial safety is to understand the harmful effects of hazards. Industrial safety refers to the protection of workers from the major industrial accidents (Pharmaceutical Conferences, 2016).

\section{Primary Laboratory Security}

In most of the workplaces, personnel must be conscious regarding to health, well-being and safety. Workers should be compelled to follow additional precautions when working in hazardous and risky environments. It must be confirmed to keep up basic laboratory safety by following primary steps according to Abdul Hafeez et al. (2020).

- Immediately cleaning of all spillages

- Sustain a tidy and orderly work place

- Washing hands frequently

- Wear a laboratory jacket or apron

- Secure smoke free environment in the laboratory

- Labelling of containers correctly

- Wearing of eye protective materials

- Wear clothing that coating the skin

- Eating in laboratory is strictly prohibited

- Regular checkup of glassware for crack and ensure that all equipment is safe and ready to use

- Corridors must be clean and clear

- Daily conduct of risk assessments

\section{Assessments of Risk in Laboratory}

The main motive of the Administration of health and safety at work regulation 1999, to find out potential danger and protect people from physical injury at work place (Burnett L et al., 1990). The Health and Safety Executive (HSE) supervise all workplace to confirm regular essential risk assessment are implemented. Pharmacies as well as laboratories are compelled to conduct risk assessments. HSE investigate workplace systems to find out whether any kind of risk. There are five step system to follow when carrying out such an assessment:

- $\quad$ Identifying any hazard by examining accident record sheets and find out potential dangers in work place.

- Note down the persons who may be affected by any dangers.

- $\quad$ Next, taking necessary step and manifesting how to mitigate the adverse effect of hazard.

- Yearly investigation of safety of work place should be done.

- Finally, evaluation should be investigated yearly to make sure that safety is being hold down in the workplace.

\section{Importance of Maintaining Data Sheets for Safety}

Different types of hazardous chemicals are frequently stored in pharmaceutical laboratories which can lead all individual at risk. Data sheets for safety make sure that all chemicals should be supplied and used in secure manure. They confirm the appropriate procedures, how to handle chemicals safely and guidance on their storage, dispatching, and necessary steps should be taken in an emergency care (Hafeez et al., 2020).

\section{Body \\ Adverse Effects of Chemicals Exposure on Human}

A person by the different ways can come into contact with hazardous chemicals are called exposure pathways. There are three initial exposure pathways: inhalation, ingestion, and skin contact. Inhalation is breathing or inhaling into the lungs. Ingestion is taking something in by mouth. Different routes responsible for entry of chemical hazards and injured the body are Absorption, Inhalation, Injection and Ingestion. Fate of chemicals exposure on human body like different Skin problems, Ache, Anthrax, 
on hand and nose causing ulcer etc., Cancer, Irritation on windpipe, Severe burns in living tissue while contact with numerous chemicals, living tissue destruction may occur by dehydration, digestion and oxidation caused by strong dehydrating agents, acids and bases and oxidizing agents respectively (Workplace health and safety, 2013; Health and Safety at Work, 2002). On the other hand, lots of harmful effect caused by hazardous chemical by the different ways. The effects of exposure not only depend on the chemical, its concentration, route of entry, and duration of exposure, but may also be influenced by personal factors such as the individual's smoking habits, alcohol consumption, medication use, nutrition, age, and sex. Harmful effects like Catching fire, Explosive or reactive, Corrosive, Irritant, Chronic organ damage, Hypersensitivity reaction and Genetic reproductive loss (Health and Safety at Work, 2002). During handling of chemicals knowledge about data sheets can help for better understanding of chemical hazards. It is advisable, always provide a safety data sheets before dealing with a chemical in the laboratory (HSE. 2013).

\section{Measures of Chemical Handling}

Improper and faulty transportation of chemicals have dangerous effects and may induce fires, blasts and chemical leakage. According to the Health and Safety at work act, precaution should be taken as during handling, transportation and distribution of toxic substances. The dangerous substances and explosive Atmospheres Regulations 2002 also be keen on that the risk 'so far as is responsibly feasibly' is removed or minimized (Bhusnure OG et al., 2018). Pharmaceutical employees use the chemical classification which helps to explains how every chemical cause hazard and identifies them properly. It also helps them to prevent explosions by correctly label and handle chemicals as well as move them. Based on ACGIH (2015) Table 1 showed any emergency many companies install safety showers. They are designed to remove hazardous liquids from protective clothing and wash skin effectively when employees come into contact with dangerous substances.

\section{Adverse Health Risks}

Chemicals have different properties which causes adverse health effects. This outcome may occur through ingestion, inhalation or skin contact. Adverse health effects can be acute or chronic. In case of typical acute health effects different signs like headaches, nausea or vomiting, and skin corrosion occur while in chronic health effects dermatitis, asthma, nerve damage, or cancer may show (Health and Safety at Work, 2002; Occupational Safety and Health Administration (OSHA)-USA).

Some chemical can cause both effects. For instance, acute effect causes immediate dizziness by solvents vapor inhalation. But chronic effect cause liver damage by breathing the individual vapors all the time for several years (Pisaniello D and Tepe S, 2012). Chemically affected organ produced some chemical symptoms are enlisted in table 2 (Pisaniello D and Tepe S, (2012); Canadian Centre for Occupational and Health Safety, 2016) some clinical symptoms are enlisted in the Table 2 .

\section{Untoward Physicochemical Risks}

The physical or chemical properties of a substance, blend or article cause health risks to workers, as they do not take place as a consequence of the biological interlink with chemical and people. Intrinsic physical hazard may occur during inappropriate handling or use of chemicals and causes injury to people and damage to different properties. Example of different physicochemical hazards comprise flammable, explosive, corrosive and oxidizing chemical (Health and Safety at Work, 2002; Occupational Safety and Health Administration (OSHA)-USA).

Table 1. Chemical hazard's identity by using Pictograms

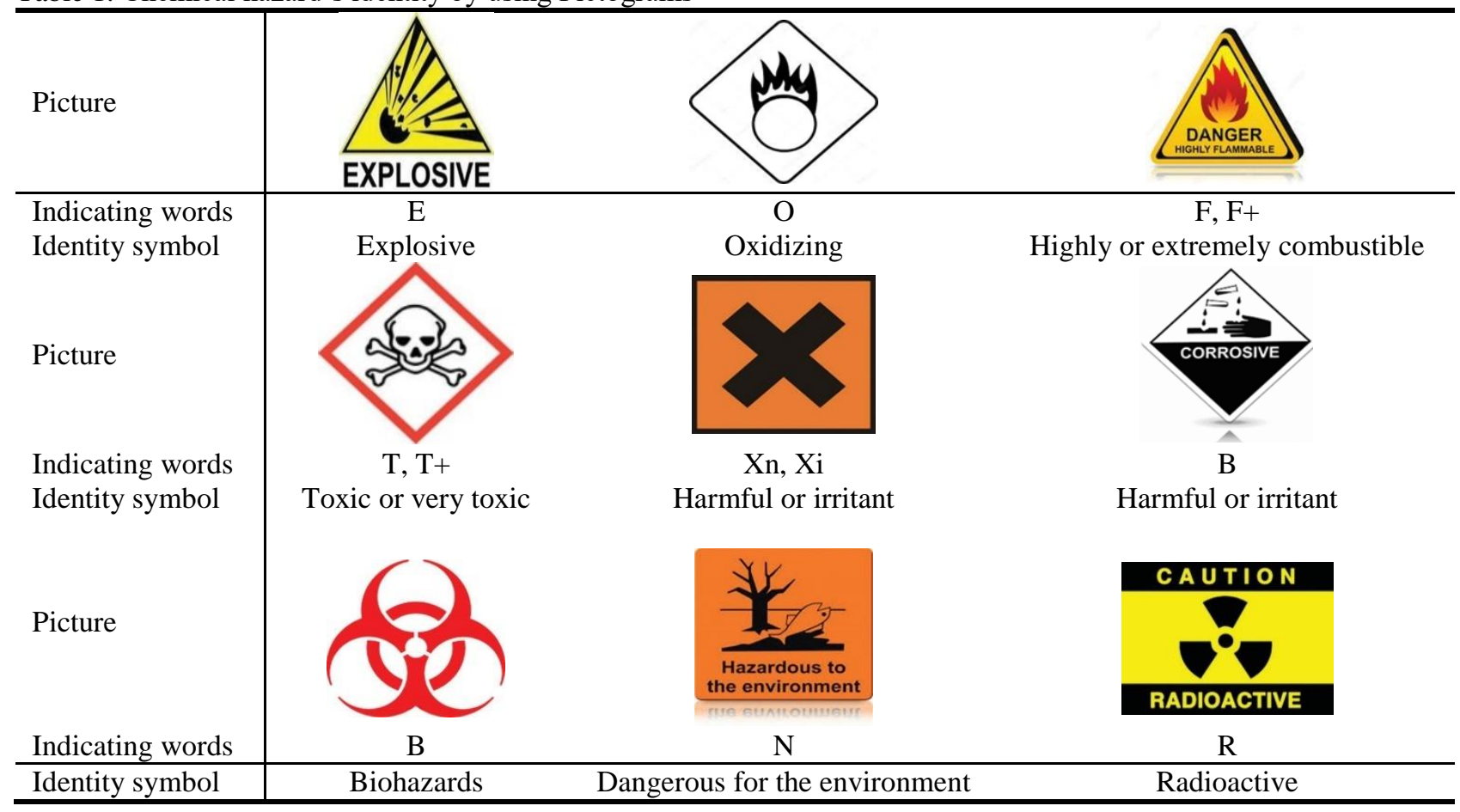


Table 2. Some chemicals produced clinical symptoms in affected organ

\begin{tabular}{|c|c|c|}
\hline Affected body organs/parts & Symptoms & Chemicals \\
\hline Head & Dizziness, headache & Solvents, smoke, ozone, paint \\
\hline Eyes & $\begin{array}{l}\text { Red, watery, irritated, grainy feeling Corneal and } \\
\text { conjunctival disturbances } \\
\text { Lens, iris, and anterior chamber disturbances } \\
\text { Posterior segment and optic nerve disturbances } \\
\text { Intra-ocular pressure elevation }\end{array}$ & $\begin{array}{l}\text { Smoke, gases, various dusts, vapors from } \\
\text { paint, and cleaners Sulfur dioxide, } \\
\text { dimethyl sulfate, hydrogen sulfide, } \\
\text { copper, Anticholinesterase agents, phenyl } \\
\text { mercuric salts ethylene glycol, Carbon } \\
\text { disulfide, warfarin, Formaldehyde, } \\
\text { ammonia }\end{array}$ \\
\hline Nose & Sneezing, coughing, rhinitis, perforated septum & $\begin{array}{l}\text { Smoke, ozone, various dusts, solvents, } \\
\text { vapors, and fumes from paint and } \\
\text { cleaners, acetic anhydride, acetic acid, }\end{array}$ \\
\hline Mouth/throat & Green tongue, salivation, sore throat & Vanadium, arsenic, mercury \\
\hline Chest and lungs & $\begin{array}{l}\text { Wheezing, coughing, shortness of breath, lung } \\
\text { cancer }\end{array}$ & $\begin{array}{c}\text { Metal fumes, various dusts, smoke, } \\
\text { solvents, vapors from } \\
\text { paint and cleaners }\end{array}$ \\
\hline Breast & Gynecomastia & Estrogens \\
\hline Stomach & Nausea, vomiting, stomach ache, diarrhea & $\begin{array}{c}\text { Some metal fumes, solvents, paint vapors, } \\
\text { long-term lead } \\
\text { Exposure }\end{array}$ \\
\hline Skin & Redness, dryness, rash, itching, skin cancer & $\begin{array}{c}\text { Solvents, chromium, nickel, detergents } \\
\text { and cleaners, paint } \\
\text { on skin }\end{array}$ \\
\hline Nervous system & $\begin{array}{c}\text { Nervousness, irritability, tremors, loss of } \\
\text { coordination } \\
\text { Drowsiness, disorientation } \\
\text { Behavioral changes }\end{array}$ & $\begin{array}{l}\text { Long-term solvent exposure, long-term } \\
\text { lead exposure CNS depressants } \\
\text { CNS depressants, convulsants }\end{array}$ \\
\hline Reproductive system & $\begin{array}{l}\text { Men: Low sperm count, damage to sperm. } \\
\text { Women: Menstrual irregularities, miscarriage, } \\
\text { damage to egg/fetus }\end{array}$ & $\begin{array}{l}\text { Lead, toluene, some other solvents, } \\
\text { ethylene oxide gas }\end{array}$ \\
\hline Pulmonary system & $\begin{array}{l}\text { Pneumonia Asthma } \\
\text { Fibrosis }\end{array}$ & $\begin{array}{c}\text { Ammonia, chlorine, oxides of } \mathrm{N}_{2} \text { Phthalic } \\
\text { anhydride, platinum salts } \\
\text { Asbestos, kaolin, silica, talc }\end{array}$ \\
\hline Cardiovascular system & $\begin{array}{l}\text { Hypotension Hypertension } \\
\text { Arrhythmia }\end{array}$ & $\begin{array}{l}\text { CNS depressants, nitrites Diphenyl } \\
\text { Trichloroethane, carbontetrachloride }\end{array}$ \\
\hline Digestive system & $\begin{array}{l}\text { Nausea, vomiting } \\
\text { Jaundice }\end{array}$ & $\begin{array}{c}\text { CNS depressants, anticholinesterases } \\
\text { Hydrazine, chloroform }\end{array}$ \\
\hline Genitourinary system & Toxic nephrosis & $\begin{array}{l}\text { Nephrotoxin (dioxane), oxalic acid, picric } \\
\text { acid }\end{array}$ \\
\hline Skin & Yellow stains, Acute eczematous dermatitis & $\begin{array}{c}\text { Picric acid, Acetaldehyde, barium } \\
\text { compounds, benzyl chloride, copper dust, } \\
\text { epoxy resins }\end{array}$ \\
\hline
\end{tabular}

Table 3. WHMI classification of chemical hazards

\begin{tabular}{l|c}
\hline \multicolumn{1}{c|}{ Class } & Examples \\
\hline Class A & $\begin{array}{c}\text { Compressed gas } \\
\text { Dissolved gas or liquefied gas } \\
\text { Class B }\end{array}$ \\
$\begin{array}{l}\text { Combustible gases } \\
\text { Combustible solids } \\
\text { Combustible aerosols } \\
\text { Reactive flammable material }\end{array}$ \\
\hline Class C & $\begin{array}{c}\text { Oxidizing materials - oxidizer and organic peroxide Oxidizer: Chlorates, peroxides, per } \\
\text { chlorates, nitric oxide, permanganates, nitrites, nitrates, metal powder easily oxidize } \\
\text { Organic peroxide: Tetrahydrofuran, diethyl ether, dioxane, methyl isobutyl ether }\end{array}$ \\
\hline Class D & Poisonous and infectious materials: cyanides, asbestos, tea, salts \\
\hline Class E & Corrosive materials: Inorganic acids and bases, hydrogen fluoride \\
\hline
\end{tabular}




\section{General Terminology Associated with Hazards}

For hygiene practice and protective management in biological and pharmaceutical laboratory, workers as well as researchers should know the following terms. According to Reddy BV et al. (2014) and UMDNJ, (2001) there are some terms bellow-

- Hazard is a term associated with a material or substance that would cause injury in a situation. A substance hazards depends on its toxicity and its constitutional characteristics.

- Industrial hazard may be defining as any situation produced by industries that may cause injury or death to personnel.

- $\quad$ Safety means free from any incident of hazard, injury or loss

- Industrial security or worker indemnity mention the defense of workers in case of industrial emergency.

- Toxicity is the capability of a substance to cause harm to the biological tissue.

- Hazardous substance defined as "those that have negative impact on workers' health after the subjection in operational mode".

Danger is a word associated with a material that in a specific setting or circumstance may cause injury. The hazards of a product depend on Its toxicity: how it is consumed, metabolized, and excreted, how it works rapidly, and the symptoms of warming. When a substance's toxicity is massive, it will be more toxic. Its constitutional features: the way in the workplace a substance can be found.

\section{Different Ways of Expression to Chemicals}

After entering the body, chemical causes health problems. According to Pruthu K, (2014). There are some pathways in which a chemical can enter into the body likewise; Respiration: Hazardous chemicals containing in the air sometime inhaled and may cause harm to the body. Skin concern: Some chemicals may harm the skin directly. Eye concern: Some chemicals may cause eye injuries and Ingestion: Some chemicals enter into the body by sharp objects injecting into skin.

\section{Chemical Hazards During Production}

In all countries, production and use of different chemicals are elementary parts in the economic prosperity. Chemicals affect to all humans in different ways and these are essentials to our feeding (pesticides, fertilizers, food additives), our health care (cleaning materials, pharmaceuticals), or our security (fuels, appliances) (Pharmaceutical Industries-blog, 2011). Different chemicals are toxic, irritant, corrosive, carcinogenic, mutagenic and flammable. Workplace hazardous materials information (WHMI) classification of chemical hazards is represented in table 3 (Pharmaceutical Industries-blog, 2011). There is a classification according to Gas Risk Management, USA; Highly flammable: Flashpoint $23^{\circ} \mathrm{C}$, Flammable: Flammability point $23-61^{\circ} \mathrm{C}$, Combustible: Flammability point $61-150^{\circ} \mathrm{C}$.

\section{Production Hazards in Pharma}

According to Occupational Safety and Health Administration (OSHA)-USA, and Health and Safety at Work (2002) there are a lot of hazards faced by laboratory personnel during research or production. Some of them are enlisted here.

- $\quad$ Strong and holding of explosive chemicals.

- Transferring, loading and unloading of chemicals to reaction utensil.

- Human errors while handling flammable chemicals

- Emission of chemical which produce air pollution from reaction vessels

- Volatile organic compounds (VOCs) releases from uncontained.

- Reaction vessels and most common VOCs include methanol, dichloromethane, toluene, ethylene glycol, $\mathrm{N}$, and acetonitrile.

- $\quad$ Leaks of effluents from waste water treatment plants or from collection sumps from process area.

\section{Use of Hazardous Gases}

Atmosphere pollution occur during vaporization of different volatile and flammable chemical at room temperature in chemical industry. The steam turns on causing fire accidents and explosions. Therefore, it needs special attention to avoid risks in storage and handling of these hazardous gases (Indian Chemical Manufacturers Association (ICMA), 2003).

\section{Toxic Gases}

Toxic gases such as ammonia, carbon monoxide, hydrogen cyanide, chlorine, nitrogen oxide, sulfur dioxide, hydrogen chloride, hydrogen fluoride and many others cause an immediate and persistent hazard to human. They are usually hazardous even at low concentration and are often characterized by threshold limit value (TLV) (Frank A and Massey R, 2004; Paul TA, Warner JB, 1998). The workers should be following the TLV limits. TLVs are only guidelines and maintain as utmost boundaries between safe and dangerous concentration (Occupational Health Safety-Canada; IARC, 2012).

\section{Objective of Health and Safety}

Based on Dikshith TS, (2013) there are some objectives which are beneficial during handling of hazardous chemical. For safety management following objectives are helpful for laboratory personnel.

- Main objective of safety is performing routine workplace inspections

- $\quad$ Supply PPE

- Develop and conduct safe work methods and rules

- $\quad$ Provide regular safety training

- Apply security rules and appropriate discipline

- $\quad$ Provide continuing property conservation practices.

\section{Safety Dimensions}

Balaji $\mathrm{G}$ et al. (2014) described some safety dimensions regarding chemical laboratory safety. Some of safety dimensions are given below-

- A "chemical hazard pocket guide" should be consulted before starting work with a chemical.

- It is prohibited to eat, drink, or smoke where chemicals are used. 
- After contamination of Clobbers with chemical or wet with water, it should be removed.

- Not only Eyes but also skins should be washed with affluence of water after an accident.

- $\quad$ Face mask should be employed in toxic dust or gases

- Workers working in antibiotic-related products must be changed routinely

- Whenever a dust allergy or respiratory problem precipitates, the worker should immediately be far away from the workplace and anaesthetize proper health care.

- In case of gas leakage, the exhaust fans should be started, and all the source of fire should be mitigated.

\section{Protection in Pharmaceutical Laboratory or Safety in Workplace}

Protection or safety in laboratory is a fundamental responsibility of all individuals to create a safe workplace. Balaji G et al. (2014); Pharmaceutical supply chain, Pharma industries blogs pots, 2011, describes the followings-

- Chemical substances hazards exist and befall round in the workplace. All individual workers must act regarding safety for all the time.

- Establish and refine the rights and safety in all workplaces.

- $\quad$ Bring up workers in the construction and protection of safe workplaces.

- Interfere when security liabilities are not evolved.

- $\quad$ Provide information and funds on security issues.

- Safety management system (SMS) is a component of management system of an establishment which review the general management visibility and system to reach the goal. An SMS have different inputs such as:

- The purpose of reviews

- Consideration of workplace reviews.

- Plan of reviews.

- Types of hazards to be improve in a workplace

- Information needed to whole a review report.

- $\quad$ Time taken for a reviews

- Frequency of reviews

- To identify the overall performance of the SMS in confirmation by periodic audits, with routine monitoring of performance. The results are wont to make essential developments.

- The SMS requires periodic critical review of workplace as well as workers to maintain and prevent the possible incidents of hazards, accidents, and related matter for the necessary action.

- Periodical workplace review by a review team to realize the actual problems.

\section{Rules for Chemical Hazards}

The chemical management confide in a mix of global mechanisms, multilateral environment agreement and deliberate advantages including a globally combined system of classification as well as labeling of different chemicals, the policy of international chemicals management and accountable care. Regulative and administrative measures are introduced in many countries to deal with chemical hazards. In 1992, (the Rio Earth Conference) gave rise to the
Agenda 21 report 2. This report summarized the responsibilities of countries toward the achievement of sustainable development and was adopted by heads of Government in over 150 countries. Chapter 19 of agenda 21 addresses the environmentally sound management of hazardous chemicals for all countries, (Pharma industries blogs pots, 2011) including basic programs for:

- Adequate legislation

- Information collection and distribution.

- $\quad$ Risk assessment and explication capacity.

- Establishment of risk guidance policy.

- Implementation and enforcement capacity

- Contaminated sites as well as affected person's rehabilitation capacity.

- $\quad$ Effective education project.

- Capacity to report to emergencies.

Inductions and Liabilities in Implementing the Laboratory Standard

The following are the National Research Council's recommendations concerning the responsibilities of various individuals for chemical hygiene in laboratories.

\section{Chief Executive Officer}

- Tolerates terminal responsibility for chemical hygiene within the facility

- Provide regular assist for institutional chemical hygiene

\section{Role of Hygiene Officer for Chemical Handling}

- Exhibits and appointments relevant chemical hygiene policies and practices.

- Counselors' arrival, use, and discarding of different chemicals in lab.

- Confirms that adequate audits are maintained.

- Helps project directors to develop safeguard and adequate facilities.

- Look for different ways to improve the chemical hygiene program.

\section{Role of Laboratory Supervisors}

In laboratory, laboratory supervisors have general responsibility for chemical hygiene.

- Assure that laboratory workers know and strictly follow the chemical hygiene rules.

- Confirm that protective equipment is available and in working order.

- Secure that applicable and fruitful training has been provided.

- $\quad$ Provide regular, formal chemical hygiene

- $\quad$ Provide routine inspections of emergency equipment.

- $\quad$ Ordain the desired levels of PPE and equipment.

- Ascertain that facilities and training for the use of any material being ordered are adequate.

\section{Role of Laboratory Workers}

- Intention and condiment each operation in unison with the chemical hygiene procedures, including the use of PPE and Engineering controls, as applicable. 
- Good personal hygiene practices should be developed.

- All hazard and possible chemical exposures should be report immediately.

\section{Basic Practices for Safety Management}

Safety performance is important aspect that need to be take into consideration. Safety performance is defined as the quality of safety related work, and its improvement in organization can increase its resistance or robustness and lower risk of accidents (Nevhage and Lindahl, 2008). Good safety performance and high productivity are congenial (Memarian, 2017). Practice of safety management is crucial to improve proper management of safety organization. Safety management practices includes management commitment, employee's involvement, safety training, safety communication and feedback, safety rules and procedure, safety promotion and various safety related policy (Vinodkumar and Bhasi, 2010).

To lower the risk of accident at workplace management commitment plays a significant role. In addition, it also reduces the consequence of the management of safetyrelated issues, reflected in the care and support given to execute safety related program (Vinodkumar and Bhasi, 2010; Hsu, 2008). Regular safety related training for the employees on safety practices will helps to reduce accidents and injuries at workplace (Cooper, 2000). Any suggestion, comment on matters of safety should be accepted by the management to develop a well-organized protocol on safety issue to reduce risk of workers at workplace (Vredenburgh, 2002).

\section{Different Challenges of Workplace}

Challenges in laboratory as well as in the workplace are very common that faced by the workers. The followings are some major challenges in workplace.

- Enhancing grant and depiction of existing regulations.

- $\quad$ Expanding hazard assessments and monitoring.

- Improving administration capacity and raising perception.

- $\quad$ Minimizing generation of precarious chemicals and unsafe wastes.

- The assumption of additional proactive as well as precautionary policies and different management approaches is ultimately needed to induce necessary environmental and human health protection standards.

\section{Different Universal Regulatory Agencies in the World}

There has relationship between globalization and the emergence of global norms which play an important role to control pharmaceutical quality. Around all over the world researcher emphasis on intellectual property (IP) rights, though the state's capacity to manage the pharmaceutical market and variations in regulatory practices (Sell S, 2003). The World Trade Organization's Agreement (WTO) implements Trade-Related Intellectual Property Rights (TRIPS). It was studied that intellectual property and its effects on pharmaceutical markets has taken on a diluvial nature. Researcher proved that the process through which the Treaty was negotiated (Sell S, 1995; Sell S, 2003; Jawara F and Kwa A, 2003), the resulting backlash at Doha (Haakonsson SJ and Richey LA, 2007; Matthews D, 2004), the increasing "tightening" of the TRIPS regime (Fink C and Reichenmiller P, 2006; Roffe P, 2004), the process of TRIPS implementation and the flexibilities pursued under the treaty (Shadlen K, 2004; Deere C, 2009; Abbott FM and Dukes G. 2009; Correa CM. 2011; Be all R and Kuhn R, 2012; Sampat B and Shadlen K, 2013; Shadlen K, 2014). These studies will help for better understanding of the global and national pharmaceutical markets, their focus on drug ownership rights has overlooked the capacity of states to regulate the quality of the drugs consumed by their citizens. As a result, the pharmaceutical sector and its governance has become a flashpoint for conflict over the ownership rights, access, and marketing of pharmaceutical products (Correa CM, 2000). These are specially associated with different chemicals, variety of drugs, and petrochemicals are many and in briefly as following:

\section{- US EPA}

- Insecticides Act, 1968. Ministry of Agricultures and Cooperation, Government of India, Pest Management Regulatory Agency (PMRA), Health Canada.

- Federal Insecticide, Fungicide, and Rodenticide Act (FIFRA), united states.

- National Toxicology Program, United states.

- National Administration of Drugs, Food, and Medical Technology, Argentina.

- Federal Institute for Drugs and Medical Devices, Germany.

- Medicines and Healthcare Products Regulatory Agency, United Kingdom.

- $\quad$ World Health Organization (WHO).

International Conference on Harmonization, Geneva, Switzerland.

\section{Conclusions}

Acquaintance should be created among workers to take care of safety and private hygiene. In pharmaceuticals. Personal hygiene must be strictly pursued by the workers in pharmaceuticals for the security of the products that are consumed by the people. It's emphasized that personnel should receive proper training in medicine handling techniques and medicine protection ethics; and may be bear in mind of the danger of unhygienic condition and fewer protective management practices. The imperative requirement is mastered reconsideration in production processes by taking into consideration the health consequences on personnel from the rudiments. Consequently, personal hygiene and protective management plays an important role in providing safe, wholesome, and hygienic medicinal products to the people for his or safety against any infection or intoxication.

\section{Conflict of interest}

All the authors declared; they have no conflict of interest. 


\section{References}

Abbott FM, Dukes G. 2009. Global pharmaceutical policy. London and New York: Edward Elgar; 2009.

Abdul Hafeez, Shmmon Ahmad, Anjoo Kamboj, Mumtaz Ahmad, Anmar AL-TAIE, Sameera Ali Siddiqui, Isha Talwar. 2020. Hazards and Safety Managements in Pharmaceutical Industry. International Journal of Applied Research, 6(5): 01-07.

ACGIH, 2015. Threshold Limit Values for Chemical Substances and Physical Agents, and Biological Exposure Indices. http://dl.mozh.org/up/acgih-2015.pdf

Balaji G, Potdar A, Unnikrishnan S. 2014. Environmental legislation for chemical management in India: An agenda. J Environ Res Dev, 9:494-506.

Bassam Abdul Rasool Hassan 2012. Pharmacological and Toxicological Effects of Chemotherapy on Cancer Patients in This Era and The Role of Open Access Journals in This Matter. International Journal of Clinical Pharmacology and Toxicology. 1(3e), 1. doi: dx.doi.org/10.19070/2167-910X$120003 \mathrm{e}$

Be all R, Kuhn R. 2012. Trends in compulsory licensing of pharmaceuticals since the Doha declaration: a database analysis. PLoS Med, 9: e1001154.

Bhusnure OG, Dongare RB, Gholve SB, Giram PS. 2018. Chemical hazards and safety management in pharmaceutical industry. Journal of Pharmacy Research, 12(3): 357-369.

Burnett L, Lunn G, Coico R. 1990. American Chemical Society, Safety in Academic Chemistry Laboratories. 5th ed. Biosafety: Guidelines for Working with Pathogenic and Infectious Microorganisms. Currents Protocols in Microbiology; 2009 13:1A.1.1.-1A.1.14.

Canadian Centre for Occupational and Health Safety. 2016 Canada: Canadian Centre for Occupational and Health Safety (CA). Available from: https://www.ccohs.ca/products/ posters/pdfs/chemical.pdf.

Chemical Hazards 2012. OHS Body of Knowledge. Australian OHS accreditation education board. https://www. ohsbok.org.au/wp-content/uploads/2013/12/17-HazardChemical.pdf?x19450

Chemical Hazards 2016. Ch. 8. Available from: http://www.Sp.ehs. cornell.edu; http://www.osha.gov/SLTC/ etools/oilandgas/glossary_of_terms/glossary_of_terms_h.ht $\mathrm{ml}$.

Correa CM. 2000. Intellectual property rights, the WTO and developing countries: the TRIPS agreement and policy options. London: Zed Books; 2000.

Correa CM. 2011. Pharmaceutial innovation, incremental patenting and compulsory licensing. South Centre Research Paper. 2011: 41.

Deere C. 2009. The implementation game: the TRIPS agreement and the global politics of intellectual property reform in developing countries. Oxford: Oxford University Press; 2009.

Dikshith TS. 2013. Hazardous Chemicals: Safety Management and Global Regulations. Boca Raton, Florida (US): CRC Press (Taylor and Francis Group); c2013.

Fink C, Reichenmiller P. 2006. Tightening TRIPS: intellectual property provisions of U.S. free trade agreements. In: Newfarmer R, editor. Trade, Doha, and development: a window into the issues. Washington, D.C: The World Bank; 2006. p. 285-300.

Food and Drug Administration (FDA). 2020. Office of Regulatory Affairs, Division of Field Investigations. (Current Edition). Investigations Operations Manual. Available from: https://www.fda.gov/media/113432/download

Frank A, Massey R. 2004. The True Costs of Reach. Copenhagen: Nordic Council of Ministers; 2004.

Gas Risk Management-a Safer Approach to Monitoring for Hazardous Gases. California (USA): Sierra Monitor Corporation; Technical reprint TR002. Available from: http://www.sierramonitor.com/assets/ bltb2ed9a415adbde79/SMC\%20Technical\%20Reprint\%20$\% 20$ Gas\%20Risk\%20Management.PDF.
Haakonsson SJ, Richey LA. 2007. TRIPs and public health: the Doha Declaration and Africa. Development Policy Review, 25:71-90.

Hazard Guidelines-Hazardous Material Spill. Ann Arbor: University of Michigan, Division of Public Safety and Security; 2011. Available from: http://www.dpss.umich. edu/docs/HazardGuidelines- HazardousMaterialSpill.pdf.

Health, Safety at Work. 2002. An Act to make provisions relating to health and safety at work and for connected purposes. https://www.ilo.org/dyn/natlex/docs/

ELECTRONIC/60975/62245/F1118521702/BHS60975\%20.pdf

Herman AM. 2020. Hazard communication guidelines for compliance, U.S. department of labor occupational safety and health administration, 2000. https://www.osha.gov/ Publications/osha3111.html

HSE, 1999. Management of Health \& Safety at Work Regulations 1999. Available from: https://www.hse.gov.uk/ pubns/hsc13.pdf

HSE, 2013. The Dangerous Substances and Explosive Atmospheres Regulations 2002. $2^{\text {ed }}$ edition. https://www.hse.gov.uk/pUbns/priced/1138.pdf

Hsu SH, Lee CC, Wu MC, Takano K. 2008. A cross-cultural study of organizational factors on safety: Japanese vs. Taiwanese oil refinery plants. Accident Analysis \& Prevention, 40(1): 24-34.

Hughes Safety Showers 2020. Health \& Safety in the Pharmaceutical Industry Published on 8th June 2016. http://www.lawplainandsimple.com/legal-guides/article/ health-and-safety-in-the-pharmaceutical-industry

IARC, 2012. A Review of Human Carcinogens: Radiation. Vol. 100D. Lyon: IARC; 2012.

Indian Chemical Manufacturers Association (ICMA). 2003. KPMG and Chemtech Foundation: The Indian Chemical Industry -New Directions, New Hope; 2003. Available from: http://www.icma.org.

International labour organization (ILO). 2020. Major hazard chemicals 8, https://www.ilo.org/wcmsp5/groups/public/--ed_dialogue/---lab_admin/documents/publication/wcms_ 735655.pdf

Jawara F, Kwa A. 2003. Behind the scenes at the WTO. London: Zed Books; 2003.

Matthews D. 2004. WTO decision on implemenationa of paragraph 6 on the DOHA declaration on the TRIPS agreement and public health. J Int Econ Law, 7:73-107.

Memarian B. 2017. Supervisor Practices for Productivity and Safety: A Hot Asphalt Roofing Case Study, 16-30.

Nevhage B, Lindahl H. 2008. A Conceptual Model, Methodology and Tool to Evaluate Safety Performance in Organization, 117.

Occupational Health Safety, Canada. Available from: http://www.cpsa.ab.ca/Libraries/Res/ Guideto Occupational Health Safety-A Physicians Guide. sflb. ash.

OSHA-Occupational Safety and Health Administration (WOSH Specialist Training Supplemental Module). Washington, DC (US): United States Department of Labor. Available from: https://www.osha.gov/dte/ grant materials/fy11/sh-2224011/ChemicalHazards.pdf.

Pal M. 2007. Zoonoses. Second Edition. Satyam Publishers, Jaipur, India.

Paul TA, Warner JB. 1998. Green Chemistry: Theory and Practice. Oxford: Oxford University Press; 1998. CDC Chemical Safety - NIOSH Workplace Safety and Health Topic. Available from http://www.cdc.gov.

Pharma industries blogs pots. 2011. Available from: http://www.Pharmaindustries.blogspots.2011/07.

Pharmaceutical Conferences. 2016. Pharmacovigilance and pharmaceutical industry. Omics international organization, 2016. https://www.pharmaceuticalconferences.com/omicsinternational/ 
Pharmaceutical Industries: Industrial Hazards. India: Blogger (Awesome Inc.); 2011. Available from: http://www.pharmaindustries.blogspot. in/2011/07/industrial-hazards.html.

Pharmaceutical supply chain. Available from: www.pharmaceuticalsupplychain.org

PIG, 2019. Pharma Industry Guidelines. Personal Protective Equipment (PPEs)-Safety Guideline. https://pharmastate.blog/personal-protective-equipmentppes-safety-guideline/

Pisaniello D, Tepe S. 2012. Chemical Hazards. In: HaSPA (Health and Safety Professionals Alliance), the Core Body of Knowledge for Generalist OHS Professionals. Australia: Safety Institute of Australia Ltd; 2012. Available from: http://www.ohsbok.org.au/wp-content/ uploads/2013/12/17Hazard-Chemical.pdf?x71776.

Pruthu K. 2014. Organic Solvents-Health Hazards. J Chem Pharm Sci, 3:83-6.

Reddy BV, Sandeep P, Navaneetha K, Ujwala P. 2014. Review on industrial hazards and its prevention. Int J Med Pharm Res, 2:492-502. Available from: https://www.researchgate.net/ profile/B_Reddy7/publication/275518968_Pulsatile_Drug_ Delivery_System-A_Review/

links/553e22cc0cf294deef6fba29/Pulsatile-Drug-DeliverySystem-A- Review.pdf.

Roffe P. 2004. Bilateral agreements and a TRIPS-plus world: the Chile-USA Free Trade Agreement. QIAP. 2004; http://www. quno.org/sites/default/files/resources/FTAs-TRIPS-plusEnglish_0.pdf

Sampat B, Shadlen K. 2013. The form and effectiveness of policies to limit secondary pharmaceutical patents in Brazil and India. Annual Meeting of the American Political Science Association. 2013.

Sell S. 1995. Intellectua1 property protection and antirust in the developing world: Crisis, coercion and choice. Int Organ, 49:315-50.
Sell S. 2003. Private power, public law: the globalization of intellectual property rights. Cambridge, UK: Cambridge University Press; 2003.

Shadlen K. 2004. Patent politics: the political economy of intellectual property rights in Latin America. Presented at the annual meeting of the International Studies Association. Montreal, Quebec, Canada 2004.

Shadlen K. 2014. International change and national responses: social coalitions and patent politics in Latin American in the 1990s. Prepared in preparation for the Meetings of the Latin American Political Economy Network. 2014; Santiago, Chile.

University of Medicine and Dentistry of New Jersey (UMDNJ). 2001. Annual Refresher on Health and Safety for Hazardous Waste Site Investigation Personnel. New Brunswick, NJ: University of Medicine and Dentistry of New Jersey - School of Public Health, Office for Public Health Practice, Centers for Education and Training; 2001.

Vinodkumar MN, Bhasi M. 2010. Safety Management Practices and Safety Behaviour: Assessing the Mediating Role of Safety Knowledge and Motivation. Accident Analysis and Prevention, 42(6): 2082-2093.

Vredenburgh AG. 2002. Organizational safety: which management practices are most effective in reducing employee injury rates? Journal of Safety Research, 33(2): 259-276

Workplace health and safety. 2013. Managing risks of hazardous chemicals in the workplace Code of Practice 2013. Available from: https://www.worksafe.qld.gov.au/data/assets/pdf_file/ 0018/23652/managing-risks-of-hazardous-chemnicals-cop2013.pdf 